\title{
KONSEP PENGAWAS DALAM PERSPEKTIF AL-QUR'AN: Upaya Meningkatkan Kualitas Pengawas Pendidikan di Lingkungan Kementerian Agama
}

\author{
ABD MUTTHALIB ABDULLAH, SYAHRUDDIN USMAN, ARIEF HALIM, AHMAD HAKIM \\ Universitas Muslim Indonesia, Makassar \\ Email: amutthalib.abdullah@gmail.com, syahruddin.usman@uin-alauddin.ac.id, \\ ariefhalim@gmail.com, ahmadhakim@gmail.com
}

\author{
Article History \\ Received April 24, 2021; Revised June 01, 2021; Accepted June 05, 2021
}

\begin{abstract}
Supervisor Concept In The Qur'an: The Efforts To Improve The Quality Of Education Supervisors In Environment Ministry Of Religion

This paper show that supervisors are the highest teaching profession, according to the attitudes described in the Qur'an. The data collected from essential Islamic sources, the Qur'an, and the literature study approach as a model. It found that first, the wrong view of the supervisor's profession makes the supervisor's attitude less responsible. Second, there is a lack of understanding of the importance of the supervisor's role in education. For this reason, the supervisor must be able to understand the message of the AlQur'an. Thus, the teachings of the Koran are a better solution for the guide. A mentor Al-Qur'an will make him a role model in the world of education. For this reason, misperceptions about the supervisor's profession must correct based on the supervisor's concept as stated in the Al-Qur'an. This paper suggests that to improve the quality of a supervisor, he must refer to stated in the Qur'an regarding supervisors.
\end{abstract}

Keywords: Education Supervisor, Supervisor Characteristics, Supervisor Qur'ani.

\begin{abstract}
Abstrak: Konsep Pengawas dalam Perspektif Al-Qur'an: Upaya Meningkatkan Kualitas Pengawas Pendidikan di Lingkungan Kementerian Agama

Tulisan ini ingin menunjukkan bahwa pengawas adalah profesi tertinggi dari guru dan harus dijalankan sesuai dengan sikap yang digariskan oleh Al-Qur'an. Data penulisan ini dikumpulkan dari sumber dasar Islam, Al-Qur'an, dan pendapat ahli tafsir terkait dengan konsep pengawas dengan studi pustaka sebagai model pendekatan. Ditemukan bahwa pertama, pandangan keliru terkait profesi pengawas telah mereduksi sikap pengawas menjadi kurang bertanggungjawab. Kedua, ketidakpahaman akan pentingnya peran pengawas dalam pendidikan. Untuk itu, Pengawas harus mampu memahami pesan AlQur'an. Dengan demikian, ajaran AI-Qur'an menjadi solusi bagi para pengawas untuk lebih baik. Bahkan, dengan Al-Qur'an, pengawas akan menjadikan dirinya teladan di dunia pendidikan. Untuk itu, salah persepsi akan profesi pengawas harus diluruskan didasarkan pada konsep pengawas yang digariskan oleh AlQur'an. Tulisan ini menyarankan bahwa untuk meningkatkan kualitas diri pengawas, maka harus merujuk pada apa yang digariskan Al-Qur'an terkait pengawas.
\end{abstract}

Kata Kunci: Pengawas Pendidikan, Karakteristik Pengawas, Pengawas Qur'ani 


\section{PENDAHULUAN}

engawas pendidikan dalam lingkungan Kementerian Agama adalah jabatan buangan, ditempati para ASN Kementerian Agama dari lingkungan pendidikan

Islam sebelum memasuki masa pensiun. Sehingga, profesi pengawas tersebut tidak ditekuni secara serius dan dianggap jabatan tidak penting (Direktorat Pembinaan Pendidikan Agama Islam pada Sekolah Umum, 2000). Selain stigma tersebut, juga disebabkan karena pengawas pendidikan belum menjalankan fungsi secara efektif dalam menjalankan tugas profesionalnya (Thaib, et al., 2005). Hal tersebut disebabkan pengawas memiliki kompetensi yang sangat rendah (Direktorat, 2000), sehingga tidak memberi manfaat bagi lembaga pendidikan yang diawasinya. Padahal pengawas pendidikan adalah jabatan tertinggi dari profesi guru ASN, setelah melewati jenjang menjadi guru, wali kelas, pembimbing atau kepala sekolah/madrasah.

Sejauh ini studi tentang pengawas cenderung melihat pada aspek pelaksanaan tugas dan fungsi pengawas. Pelaksanaan tugas pengawas masih belum efektif (Erwin et al., 2020; Kurniati, 2020). Hal ini terjadi karena pengawas belum menerapkan sistem profesionalisme dalam bekerja. A.M. Wibowo dan Siti Muawanah (2019) menemukan hal yang senada dengan Erwin bahwa kualitas diri pengawas masih sangat perlu ditingkatkan. Hal ini tercermin dari kinerja pengawas yang masih rendah (Beddu dan Fatnah, 2018).

Studi lain melihat terkait kompetensi pengawas pendidikan (Aguslani, 2019) yang melihat bahwa kualitas pengawas masih butuh ditingkatkan. Bahkan studi yang dilakukan Pagga, et.al (2020) memperlihatkan bahwa pengawas masih dinilai tidak memuaskan kinerjanya di kalangan para guru PAI. Musdalifah (2020) melihat bahwa sikap pengawas yang otoriter masih sering terjadi. Walaupun demikian perannya sangat dibutuhkan bagi pengembangan karier guru di sekolah/madrasah (Kurniati, 2020). Padahal pengawas tidak menyangkut aspek tersebut saja. Ada satu aspek yang luput diperhatikan dengan seksama oleh pengkaji terdahulu, yakni aspek karakter pengawas merupakan hal terpenting yang untuk diperhatikan dalam kajian terkait dengan pengawas. Pola pengawasan dapat diberikan melalui pelatihan dan pendidikan kepada pengawas, tetapi karakter membutuhkan waktu yang lebih lama, karena ini terkait dengan diri terdalam seseorang.

Tulisan ini ingin melengkapi kekurangan studi-studi terdahulu yang kurang memperhatikan aspek karakter sebagai letak masalah, rendahnya mutu pengawas dan tidak maksimalnya kinerja pengawas. Secara khusus tulisan ini ingin menunjukkan bahwa karakter pengawas menjadi faktor penting dalam meningkatkan mutu dan kinerja pengawas pendidikan di kementerian agama. Sejalan dengan itu, maka tiga pertanyaan yang dijawab dalam tulisan ini: (1) bagaimana wujud karakter yang mampu menghasilkan pengawas yang berkualitas dan bertanggung jawab, (2) faktor apa saja yang mempengaruhi karakter pengawas dalam meningkatkan mutunya, dan (3) bagaimana karakter dapat berimplikasi pada 
peningkatan kualitas kinerja dan tanggung jawab pengawas. Jawaban atas tiga pertanyaan tersebut memungkinkan dipahaminya dasar-dasar pemikiran yang digunakan sebagai landasan melakukan pendidikan karakter bagi pengawas pendidikan dalam rangka meningkatkan mutu dan kinerjanya.

Tulisan tentang karakter pengawas kaitannya dengan masalah mutu dan kinerja pengawas ini didasarkan pada argumentasi bahwa karakterlah yang menjadi fondasi bagi setiap orang termasuk pengawas di dalam memaksimalkan potensi dirinya di setiap pekerjaan yang dilakukan. Karakter yang dimaksud mampu meningkatkan mutu dan kualitas kinerja pengawas adalah karakter yang bersumber dari Al-Qur'an, sumber paling fundamental dalam Islam. Karakter pengawas qur'ani menjadi solusi bagi peningkatan mutu dan kualitas pengawas pendidikan di lingkungan kementerian agama. Karakter yang sepatutnya diteladani setiap pengawas pendidikan di lingkungan kementerian agama yang hampir seluruhnya adalah berkeyakinan Islam sebagai ajaran yang paripurna dan memiliki segala kebutuhan hidup manusia, termasuk di dalamnya ajaran tentang akhlak yang menjadi cerminan dari keimanan dan terimplementasi dalam hidup setiap muslim, termasuk yang berprofesi sebagai pengawas.

Faktor yang amat strategis dalam pembinaan sikap dan tingkah laku seorang pengawas muslim adalah keyakinan (iman)-nya akan kehadiran dan keesaan Tuhan (Yunus, 1989). Hal ini ditegaskan dalam hadis Nabi SAW, bahwa "Ihsan yaitu engkau beribadah kepada Allah seolah-olah engkau melihat-Nya. Jika engkau tidak mampu melihat-Nya, maka ketahuilah bahwa Dia selalu melihatmu" (Naisaburi, n.d.: 22). Namun sikap ini belumlah cukup sebagai seorang pengawas haruslah berkeyakinan bahwa "Tidak ada Tuhan yang patut disembah atau dipatuhi selain Allah" (QS. 5: 73; 7: 158; 21: 25; 23: 23, 32, 116; 25: 3; 28: 70, 88; 43:45, 84; dan 47: 19). Keyakinan inilah yang mendasari sikap hidup seorang muslim (pengawas), baik kehidupan pribadi, hubungan dengan sesama muslim maupun sikapnya dalam pergaulan hidup di tengah-tengah masyarakat.

Tauhid, keyakinan akan keesaan dan kemutlakan Tuhan (Yunus, 1989) juga menjadi tujuan hidup tiap muslim, baik dalam kehidupan pribadi, kehidupan antar sesama muslim maupun dalam hubungan dengan orang-orang yang berbeda keyakinan. Mengenal Tuhan dapat dimulai dengan menelaah kesombongan manusia. Manusia modern yang mengagungkan akal dan merasa memiliki kemampuan untuk melakukan apa saja, telah memperlihatkan wujud kesombongan manusia yang dapat diidentifikasi ke dalam tiga macam kesombongan: merasa mampu menyelesaikan tiap masalah tanpa uluran tangan orang lain, bahkan juga pertolongan Tuhan. Kedua, kesombongan akan kebenaran pikiran. Bahwa mampu menemukan kebenaran dan secara konsisten dapat berjalan di atas kebenaran pikirannya. Ketiga, merasa dapat mencapai puncak kebahagiaan hanya dengan halhal yang duniawi dan manusiawi (Yunus, 1989). 
Pengawas pendidikan menurut Peraturan Menteri Pendidikan RI Nomor 12 Tahun 2007 tentang Standar Pengawas Sekolah/Madrasah menitikberatkan pada kompetensi personal pengawas dan kompetensi profesional pengawas. Sedangkan dalam Peraturan Menteri Negara Pendayagunaan Aparatur Negara dan Reformasi Birokrasi Nomor 21 Tahun 2010 tentang Jabatan Fungsional Pengawas Sekolah dan Angka Kreditnya menjelaskan bahwa pengawas memiliki tugas dan tanggung jawab untuk melaksanakan pengawasan akademik dan manajerial satuan pendidikan. Lebih lanjut dijelaskan dalam Pasal 1 Ayat (2) bahwa pengawas sekolah adalah Pegawai Negeri Sipil (PNS)-ASN sekarang ini-tugas dan tanggung jawab dalam dua hal yaitu: pengawasan akademik dan pengawasan manajerial.

Selain itu, Kementerian Pendidikan juga mengeluarkan Peraturan No. 143 Tahun 2014 tentang Petunjuk Teknis Pelaksanaan Jabatan Fungsional Pengawas Sekolah dan Angka Kreditnya sebagai penjabaran dari Peraturan yang dikeluarkan oleh Kementerian Negara Pendayagunaan Aparatur Negara dan Reformasi Birokrasi Nomor 21 Tahun 2010 tentang Jabatan Fungsional Pengawas Sekolah dan Angka Kreditnya. Aturan ini berisi petunjuk teknis bagi pengawas pendidikan untuk melaksanakan tugas dan tanggung jawabnya. Demikian juga dijelaskan dalam Peraturan Menteri Agama RI No. 2 Tahun 2012 tentang pengawas dan pengawas pendidikan Islam bahwa pengawas merupakan tenaga profesional berstatus ASN yang memiliki kewenangan melakukan pembinaan akademik dan manajerial (Undang-Undang Pendidikan Nasional, 2011).

Kedua peraturan Menteri tersebut menjelaskan apa yang menjadi tanggung jawab dan bagaimana kriteria dari seorang pengawas pendidikan. Pengawas pendidikan tidak hanya dibebankan tanggung jawab untuk mengawasi akademik dan manajerial lembaga pendidikan tetapi mereka juga diwajibkan memiliki kecakapan personal dan kecakapan profesional. Kecakapan personal terkait dengan akhlak/etika dan keterampilan kepengawasan, sedangkan kecakapan profesional terkait dengan kemampuan menguasai ilmu tentang kepengawasan baik manajerial maupun akademik (Thaib, et al., 2005).

Pengawasan merupakan fungsi terakhir dari kegiatan manajemen, yaitu fungsi controlling (Chairunnisa, 2016; Samsirin, 2015). Pengawasan dimaksudkan untuk menjamin tujuan-tujuan organisasi pendidikan dapat tercapai. Fase pengawasan bertujuan untuk menilai apakah sasaran dari organisasi pendidikan yang telah direncanakan telah dicapai dengan baik atau belum. Pengawasan dilakukan secara sistematis dengan menetapkan standar mutu pendidikan sesuai dengan perencanaan. Dengan terlebih dahulu, merancang sistem informasi umpan balik, membandingkan kegiatan nyata dengan standar mutu pendidikan yang telah ditetapkan sebelumnya. Dengan demikian, menentukan dan mengukur penyimpangan serta mengambil tindakan koreksi yang diperlukan untuk menjamin bahwa semua sumber daya lembaga dipergunakan dengan cara yang paling efektif dan efisien dalam mencapai tujuan-tujuan lembaga. 
Pengawas harus memiliki beberapa karakter yang melekat pada dirinya, di antaranya: menjadi teladan, memiliki komitmen tinggi dalam melaksanakan tugas, penuh kasih sayang, berpenampilan rapi dan menyukai kebersihan, ramah dan sabar, suka memaafkan orang lain, sopan dan penuh hormat (RI, 2005). Profesi pengawas merupakan pekerjaan mulia, tugasnya untuk meningkatkan potensi guru tidak hanya dalam ilmu pengetahuan (transfer of knowledge) tetapi juga menanamkan nilai-nilai ilahiah dalam agama (transfer of islamic value) (RI, 2005). Selain itu, bahwa keberhasilan pengawas sangat bergantung pada komitmen yang dimiliki dalam mengembang tugas sebagai pengawas. Komitmen dan kesetiaan akan tugas melekat pada diri setiap pengawas pendidikan. Betapa pun hebatnya seorang pengawas tetapi ia abai terhadap komitmen dan tanggung jawab, maka ia akan menemui kegagalan. Selain itu, pengawas di dalam melaksanakan tugas dan fungsinya harus senantiasa memperlihatkan dan mempraktikkan sikap kasih sayang.

\section{METODE PENELITIAN}

Penulisan tentang pentingnya karakter pengawas dipilih sebagai subjek pembicaraan karena beberapa pertimbangan, pertama persoalan karakter merupakan topik sentral yang belum banyak diperhatikan pada kajian-kajian terdahulu. Kedua, karakter menjelaskan bahwa adanya hubungan sebab akibat antara perilaku yang tidak profesional dengan karakter personal pengawas sehingga membutuhkan kajian lebih komprehensif.

Penelitian ini bersifat kualitatif yang bersandar pada data sekunder yang diambil dari data riset sebelumnya dan dari sumber ajaran utama Islam, AI-Qur'an. Data yang dibutuhkan berupa hasil riset yang dilakukan terkait dengan kinerja dan tanggung jawab pelaksanaan tugas pengawas dan data atau konsep karakter yang diambil dari penafsiran ahli tafsir bercorak fikih dan tafsir bercorak l'tiqaadi (tasawuf (Syukur, 2015).

Proses penelusuran literatur dilakukan selama lima bulan terakhir dan melihat data kajian dua tahun terakhir terkait dengan pengawas dan pengawasan pendidikan di berbagai wilayah di Indonesia. Tentu saja sumber rujukan yang diambil dari jurnal-jurnal atau publikasi ilmiah lainnya dan membandingkan dengan pendapat ulama tafsir yang membahas topik yang diteliti.

Analisis data dilakukan dengan analisis isi (Krippendoff, 1993) dengan cara memilih, membandingkan, menggabungkan, dan memilah berbagai pengertian hingga ditemukan yang relevan. Hal ini dilakukan untuk menjaga konsistensi proses pengkajian dan mencegah serta mengatasi mis-informasi. Langkah selanjutnya dilakukan interpretasi atas data yang ditemukan untuk mengungkap makna dari data yang dikumpulkan. 


\section{HASIL PENELITIAN DAN PEMBAHASAN \\ Peran Pengawas dalam Pendidikan}

Pengawas satuan pendidikan adalah jabatan fungsional yang berkedudukan sebagai pelaksana teknis untuk melakukan pengawasan pendidikan terhadap madrasah dalam upaya meningkatkan kualitas proses dan hasil belajar madrasah untuk mencapai tujuan pendidikan (Pandong, 2003). Pengawas madrasah menilai dan membina penyelenggara pendidikan. Penilaian dilakukan untuk mengetahui tingkat kualitas madrasah berdasarkan kriteria yang telah ditetapkan. Sedangkan pembinaan dilakukan untuk memberi arahan, saran dan bimbingan.

Untuk menjadikan peran pengawas maksimal, dibutuhkan pengawas yang memiliki kompetensi tertentu dan harus melalui proses rekrutmen yang baik, sehingga profesi pengawas adalah buangan, tempat transisi menuju pensiun tidak terjadi. Melihat fenomena yang terjadi bahwa ketidakpuasan lembaga pendidikan atas diri pengawas jelas menggambarkan bahwa proses rekrutmen belum berjalan sebagaimana diamanatkan oleh Permendiknas No. 12 Tahun 2007 yang menghendaki kualifikasi pengawas itu memiliki standar mutu yang tinggi: S2, guru bersertifikat pendidik, atau kepala madrasah berpengalaman, telah lulus ujian kompetensi.

Pengawas pendidikan Islam juga memiliki dua fungsi utama, pengawasan akademik dan manajerial. Pengawasan akademik dimaksudkan untuk membantu para guru mengembangkan kapabilitas profesionalnya, menjamin mutu guru menjadi lebih baik dan pembinaan, penilaian, dan pelatihan profesionalisme guru (Aedi, 2014; Pagga, et al., 2020). Sedangkan pengawasan manajerial terkait dengan kegiatan pemantauan, penilaian, pembinaan terhadap kepala madrasah dan seluruh elemen sekolah lainnya dalam mengelola, mengadministrasikan dan melaksanakan seluruh aktivitas madrasah (Aedi, 2014; Musdalifah, 2020). Langkah lebih lanjut sebagaimana dikemukakan oleh Kurniati (2020) bahwa untuk meningkatkan mutu akademik dan manajerial dibutuhkan pendekatan direktif yakni supervisi langsung dengan memberikan instruksi atau mencontohkan. Hal ini dilakukan untuk guru yang kurang profesional. Sedangkan guru yang dianggap telah profesional maka pendekatan yang dilakukan adalah non-deriktif. Penulis melihat bahwa peran pengawas tidak hanya hadir sebagai profesional di bidang pengawas, tetapi pengawas juga menjadi cermin kebenaran, memberi contoh keteladan. Pengawas itu harus memulai dari diri sendiri, meningkatkan potensi dirinya dengan menyifati sifat al-Badi', al-Awwal dan al-Akhir.

\section{Karakteristik Pengawas dalam Islam}

Manusia sebagai makhluk sempurna di sisi Allah SWT.(Lihat, QS. At-Tin [95]: 4). Makna sebagai ciptaan yang sempurna tentu harus dipahami secara baik dan harus digali dan dipelajari maknanya secara mendalam. Dengan memahami kesempurnaan penciptaan manusia yang dimaksudkan oleh Allah SWT. tentu akan 
memberi gambaran seperti apa manusia yang sempurna tersebut. Hal ini pula yang harus dimiliki oleh pengawas dan khususnya pengawas pendidikan.

Secara konseptual karakteristik pengawas sebagaimana dikemukakan oleh Rivai dan Murni (2010: 835-836) sebagaimana dikutip oleh Nur Aedi bahwa dua kualifikasi kompetensi yang harus dikuasai oleh seorang pengawas, yaitu kualifikasi normatif dan kualifikasi konstruktif. Normatif untuk mendukung secara kondusif citra pendidikan sebagai sarana efektif untuk melestarikan nilai-nilai budaya atau nilai agama yang telah menjadi budaya dan telah mengakar menjadi jadi diri bangsa. Sedangkan, konstruktif untuk dapat meyakinkan tenaga kependidikan bahwa peserta didik dapat berkembang sesuai potensi yang dimilikinya melalui proses pendidikan (Aedi, 2014; Shihab, 2010).

Terkait dengan argumentasi tersebut di atas, maka kualifikasi konstruktif meliputi:

1. Menyadari secara penuh bahwa sebagai tenaga kependidikan yang memiliki etika profesional dalam melaksanakan tugas kepengawasan,

2. Memahami bahwa proses kegiatan kepengawasan cenderung tidak terlihat oleh stakeholders pendidikan sehingga kegiatan kepengawasan bukanlah kegiatan yang bersifat populis

3. Mencintai profesi kepengawasan, sehingga tanpa reserve melakukan tugas berdasarkan hati nurani,

4. Tidak berorientasi pada materi sehingga watak keserasian terinternalisasi dalam berperilaku,

5. Memahami secara mendalam fungsi reward dan punishment dalam proses pendidikan, dan

6. Menjadikan personel sekolah sebagai mitra dan menjauhi sikap arogan ketika melaksanakan tugas di sekolah (Aedi, 2014).

Dengan demikian, seseorang atau pengawas yang ingin sampai pada predikatpredikat tersebut di atas maka secara personal ia harus menjadikan dirinya sebagai cermin kebenaran (Al-Jily, 1975). Menjadi cermin kebenaran hanya didapatkan apabila seorang pengawas menyifati beberapa sifat berikut ini: Menghidupkan (alhay), Mengetahui (al-alim), Menguasai (al-qadir), Melihat (al-Bashiir), Dibutuhkan (alshamad), selain itu pengawas juga harus menyifati sifat berikut: Pencipta Pertama (al-Badi'), Pertama (al-awwal) dan akhir (al-aakhir) (Al-Jily, 1975, 2014)).

1. Menghidupkan dimaksud sebagaimana dijelaskan Quraish Shihab adalah hidup yang sebenarnya bukan sekadar hidup untuk diri sendiri, tetapi harus mampu memberi hidup dan sarana kehidupan kepada pihak lainnya (Al-Jily, 2014; Shihab, 1999). Pengawas pendidikan harus mampu menyifati sifat ini karena ia harus mampu memberi hidup kepada orang lain, dalam hal ini para guru dan kependidikan yang ada di lembaga yang diawasinya. Selain itu, pengawas juga harus senantiasa hidup di dalam setiap lembaga pendidikan, maksudnya bahwa ia harus mampu memberi roh pada perjalanan lembaga pendidikan yang berada 
di bawa pengawasannya. Hal ini secara tegas dikatakan dalam Al-Qur'an Surah Al-Baqarah [2]: 154 bahwa setelah mati pun bagi orang yang berjihad di jalan Allah, Al-Qur'an menjelaskan bahwa ia tetap hidup walaupun orang lain tidak menyadarinya.

2. Mengetahui (al-‘alim) apa yang menjadi fungsi dan tugas pokok seorang pengawas adalah hal mendasar yang harus dimiliki seorang pengawas pendidikan. Mereka harus mengetahui atau 'alim terhadap ilmu pengetahuan terkait dengan kepengawasan. Maka seorang pengawas senantiasa diperintahkan untuk menambah ilmunya. IImu yang paling penting dimiliki oleh pengawas adalah pengetahuan, sebagaimana disebutkan oleh Nabi SAW, bahwa pengetahuan bukan hanya terbatas sampai pada kemampuan mengekspresikannya dalam bentuk kata tetapi ada pula yang menyentuh hati sehingga melahirkan amal-amal yang sesuai dengan petunjuk ilahi (Al-Jily, 2014; Shihab, 1999). Sedalam itulah ilmu yang harus dikuasai oleh seorang pengawas.

3. Pengawas juga diharuskan menyifati sifat Kuasa (al-Qadir) (Shihab, 1999) yakni menjadi pemimpin tetapi tidak menjadi penindas bagi yang lain. Karena kadang kala, sifat kuasa ini dijadikan sebagai alat untuk melakukan tindakan yang melegalkan segala cara untuk berbuat sesuatu walaupun hal tersebut merugikan lembaga dan orang-orang yang berada di dalamnya. Kuasa yang digunakan secara semena-mena tentu berimplikasi kepada kerusakan terhadap lembaga pendidikan, karena merusak sistem kerja yang sejatinya harus bersifat kekeluargaan, sehingga seorang pengawas ketika meneladani sifat qadir ini haruslah memosisikan diri bahwa meyakini kuasa itu hanya milik Allah SWT, dan menyadari bahwa ia tidak dibolehkan berpikir untuk menganiaya orang lain. Karena kuasa yang dipegangnya hanya bersifat sementara dan akan beralih ke orang lain. Kuasa adalah amanah yang harus dipahami sebagai cara Allah SWT memuliakan seseorang apabila ia menjalankan dengan adil.

4. Menyifati sifat Allah SWT, Melihat (al-Bashir), menggambarkan bahwa seorang pengawas haruslah meyakini bahwa seluruh perbuatan dan tingkah laku yang dilakukan selalu dalam jangkauan penglihatan Allah SWT. sehingga seluruh perbuatan seorang pengawas senantiasa dilakukan dengan baik dan selalu didasarkan pada pandangan bahwa ia juga diawasi walaupun tidak terlihat secara kasat mata. Dengan demikian, ia akan selalu menegakkan kebijakan yang tidak merugikan siapa pun bahkan dirinya sekali pun. Imam Al-Gazali pada saat menjelaskan sifat ini, menjelaskan bahwa Isa a.s. pernah ditanya, "Adakah yang sama dengan engkau?" Beliau menjawab, “siapa yang pandangannya adalah pelajaran, diamnya adalah renungan dan ucapan-ucapannya adalah zikir, maka dia sama dengan saya (Shihab, 1999: 142; Al-Jily, 2014)." Kesadaran yang demikian inilah yang hendaknya menjadi akhlak seorang pengawas dalam upaya meneladani sifat Allah SWT. 
5. Dibutuhkan (al-Shamad) dapat dimaknai bahwa pengawas harus menjadi seseorang yang dibutuhkan di lembaga yang dipimpinnya (Al-Jily, 2014). Karena ia adalah sosok yang mampu memenuhi harapan setiap pihak di dalam lembaga tersebut. la adalah puncak harapan di lembaga yang dipimpinnya (Lihat, Shihab, 1999: 309-313).

6. Selain itu pengawas juga harus menyifati sifat berikut: Pencipta Pertama (alBadi') Pengawas haruslah orang yang selalu memiliki visi yang jauh ke depan, karena ia adalah sosok pencetus awal atau orang yang memiliki pengetahuan terkait akan ke mana arah pendidikan di lembaga yang dipimpin atau diawasinya. Sebagai misal, sebagaimana dicontohkan Al-Gazali, bahwa pengetahuan pemain catur dan pengetahuan pencipta permainan catur. Sang pencipta adalah penyebab adanya catur, sedangkan keberadaan catur adalah sebab pengetahuan pemain. Pengetahuan pencipta mendahului pengetahuan pemain, sedang pengetahuan pemain diperoleh jauh sesudah pengetahuan pencipta catur (Shihab, 1999: 115). Demikianlah gambaran seorang pengawas, ia adalah pencipta sehingga pengetahuannya harus selalu jauh lebih dulu dibandingkan orang-orang yang berada di bawa pengawasannya.

7. Pertama (al-awwal) dan Akhir (al-aakhir) adalah sifat yang harus dipraktikkan oleh pengawas pendidikan. Sosok pengawas harus menjadi teladan yang paling awal, baik dalam hal akhlak kepada Allah SWT maupun tindakan-tindakan yang berkaitan dengan dimensi sosialnya. Hendaknya ia pula tampil paling awal di dalam pentas sujud kepada Allah SWT dalam arti bahwa ia dituntut menjadi awwal al-mukminin, awwal al-muslimin serta awwal man aslam (Shihab, 1999: 329) serta mendahului semua yang maujud, mewujudkan segala yang maujud dan menciptakan segala yang ada (Al-Bagdad, n.d.: 143-145). Dalam bahasa Ki Hajar Dewantara, pengawas itu haruslah Tut Wuri Handayani. di depan, seorang pengawas harus bisa menjadi teladan di tengah lembaga yang dipimpinnya, pengawas harus bisa memberikan ide, dan di belakang, seorang pengawas harus bisa memberikan dorongan kemajuan lembaga."

Demikianlah sifat-sifat yang harus dimiliki oleh pengawas dan menjadikan sifat tersebut mencermin ia sebagai pengawas yang qur'ani. Pengawas qur'ani merupakan pengawas yang di dalam hidupnya senantiasa mempraktikkan sifat-sifat Allah SWT dalam hidupnya dan menjadikan sifat itu fondasi dalam melakukan pekerjaan-pekerjaan profesionalnya. Dengan demikian, apa yang dilakukan bukan semata-mata karena pekerjaan tetapi merupakan bentuk ibadah kepada-Nya.

\section{Pengawas Qur'ani sebagai Gagasan Alternatif}

Hidup bagi pengawas hendaknya tidak hanya terbatas pada hari ini atau sepanjang usianya di dunia saja, tetapi harus melampaui generasinya. Bahkan melampaui batas usia, jenis manusia di dunia ini. Pada dasarnya, pengawas pendidikan tidak dapat hidup abadi sebagaimana Allah SWT. dan tidak juga mampu hidup melampaui batas usianya di dunia, tetapi ia dapat melanggengkan hidupnya 
dengan keharuman namanya, bahkan setelah ia meninggal. Pengawas juga akan abadi dengan karya-karyanya yang bermanfaat, sehingga dinikmati oleh manusia sepanjang masa.

Jika demikian, hal tersebut dapat dimengerti sebagaimana dijelaskan di dalam Al-Qur'an bahwa ada orang-orang yang masih dapat menarik dan menghembuskan nafas dan masih juga berfungsi otak dan beredar darahnya, tetapi dinilai telah mati. Kenapa, karena ia tidak mendengar dan memperkenankan panggilan Allah SWT. dan Rasul-Nya, sebagaimana dijelaskan dalam Surah Al-Baqarah [2]: 154:

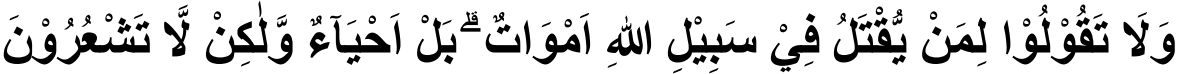

"Dan janganlah kamu mengatakan terhadap orang-orang yang gugur di jalan Allah (bahwa mereka itu) mati, bahkan (sebenarnya) mereka itu hidup, tetapi kamu tidak menyadarinya."

Ayat tersebut di atas, memakai kata في سبيل الله di dalam Al-Qur'an kata tersebut kurang lebih 65 kali disebut. 23 kali diawali dengan huruf (عن) dan selebihnya diawali dengan huruf فُ. Oleh karena itu, kata jihad dapat dipahami secara umum adalah segala kemampuan yang dicurahkan oleh manusia dalam membela diri dari keburukan, kebodohan bahkan kemiskinan, disertai ikhlas dalam melaksanakan pekerjaan yang diamanahkan Allah SWT., maka itu merupakan jihad. Demikian halnya, pengawas pendidikan yang menjalankan tugas dan tanggung jawabnya dengan amanah, maka sesungguhnya ia juga sedang jihad di sisi Allah SWT.

Dengan demikian, pendidikan berfungsi untuk mempertahankan agama Islam. Karena itu, dapat dimasukkan dalam jihad fii sabilillah. Pandangan tersebut, menggambarkan pemahaman umum bahwa kemampuan yang dicurahkan oleh manusia dalam membela dirinya dari segala keburukan dalam menegakkan kebenaran, membenahi kebutuhan masyarakat, bersungguh-sungguh dan ikhlas melaksanakannya, demikian juga pengawas pendidikan, maka semuanya adalah jihad di sisi Allah SWT.

Selanjutnya, argumentasi yang dapat dibangun bahwa manusia tidak dapat memberi hidup sebagaimana Allah memberi hidup kepada makhluk, maka solusinya adalah meneladani Allah dalam sifatnya الحي di dalam kehidupannya. Caranya adalah dengan berbuat sesuatu yang berdampak baik bagi manusia lainnya, baik secara materiil maupun secara spiritual. Pengawas pendidikan, misalnya, mempraktikkan sifat Allah tersebut dengan cara tidak menjerumuskan manusia ke dalam derita, apalagi membunuhnya. Baik dalam arti membunuh dengan mencabut nyawanya atau mencabut hak-haknya sebagai manusia.

(mengetahui) atau al-ilm (Maha Mengetahui) adalah sifat dari al-Haq yang bersifat azali (Shihab, 1999). Maka ilmu al-Haq tentang diri-Nya, dan ilmunya tentang makhluk-Nya adalah satu ilmu, yang tidak terbagi dan tidak terbilang (kutipan). 
Karena itu, apa yang menjadi fungsi dan pokok seorang pengawas adalah hal yang mendasar, harus dimiliki seorang pengawas pendidikan.

Mereka harus mengetahui atau alim terhadap ilmu pengetahuan yang terkait dengan kepengawasan. Seorang pengawas senantiasa diperintahkan untuk menambah ilmunya. IImu yang paling penting dimiliki oleh pengawas adalah pengetahuan tidak hanya sebatas sampai pada kemampuan mengekspresikan dalam bentuk kata tetapi juga mampu menyentuh hati. Hal ini dimaksudkan agar ilmu tersebut melahirkan amal-amal yang sesuai dengan petunjuk ilahi. Hal tersebut ditegaskan pada satu hadis yang disandarkan kepada Nabi saw:

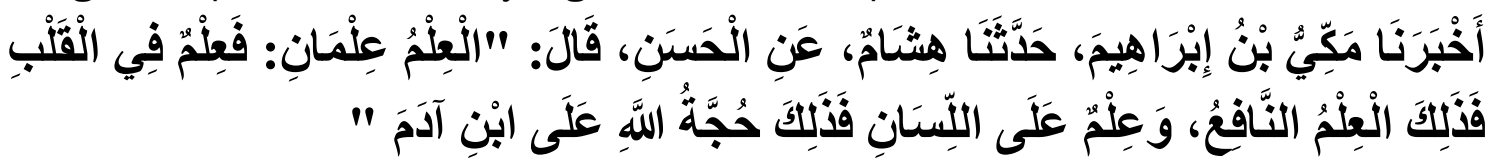

"Dari al-Hasan berkata: ilmu itu adalah dua bagian, ilmu di dalam hati (qalbu) maka itulah ilmu yang berfaedah. Sedangkan ilmu keluar dari lisan, maka itulah hujjah Allah atas anak cucu Adam (Shamad, n.d.)."

Dalam meneladani sifat al-alim, seorang pengawas hendaknya terus menerus berupaya meningkatkan ilmunya. Rasul SAW. setelah diperintahkan untuk membaca pada wahyu pertama, la juga diperintahkan untuk senantiasa berdoa. Hal tersebut ditegaskan dalam Surah Thaha [20]: 114:

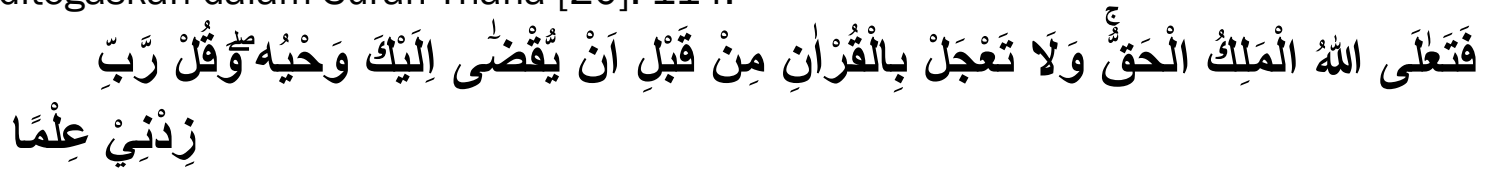

"Maka Mahatinggi Allah, Raja yang sebenar-benarnya. Dan janganlah engkau (Muhammad) tergesa-gesa (membaca) Al-Qur'an sebelum selesai diwahyukan kepadamu, dan katakanlah, 'Ya Tuhanku, tambahkanlah ilmu kepadaku.'"

Dalam upaya tersebut, pengawas dituntut supaya dapat menggunakan secara maksimal seluruh potensi yang dianugerahkan Allah kepadanya. Hal ini dimaksudkan untuk meraih sebanyak mungkin ilmu yang bermanfaat, bukan hanya mengenal "seluruh" benda-benda yakni "seluruh alam raya" yang telah diberikan Allah, yang merupakan potensi yang telah dimiliki sejak kelahiran manusia pertama. Tetapi juga ilmu yang bersifat non-empiris, yang hanya dapat diraih dengan kesucian jiwa dan kejernihan kalbu.

Setiap ilmuwan yakni pengawas dituntut untuk memberi nilai-nilai spiritual bagi ilmu yang diraihnya, sejak motivasi hingga tujuan dan pemanfaatannya. Pada dasarnya tidaklah berbeda cara dan alat-alat mendapatkan ilmu antara seseorang dengan seseorang lainnya. Hakikat ilmiah pun yang mereka dapatkan tidak berbeda karena cara dan alat serta hakikat ilmiah bersifat universal dan bebas nilai; tetapi, motivasi, tujuan dan pemanfaatan ilmu, bagi ilmuwan yang meneladani Allah SWT. dalam sifatnya, tidaklah bebas nilai tapi ia harus (بسم ريتك 
(kuasa) adalah kekuatan inti yang hanya lahir dari Allah Azza Wajalla semata. Wujudnya berupa penampakan maklumat (pengetahuan) kepada alam realitas (alam panca indera) sejalan dengan kehendak IImunya.

Dala Al-Qur'an kata "qadir" ditemukan sebanyak 7 kali. Semuanya menunjuk kepada Allah SWT, lima di antaranya dalam konteks meyakinkan mereka yang ragu tentang kekuasaan dan kemampuan-Nya mencipta manusia dan membangkitkannya setelah kematian. Sisanya, masing-masing menjelaskan konteks menurunkan mukjizat yang bersifat indrawi untuk membuktikan kebenaran rasul-Nya dan tentang menurunkan siksa bagi yang membangkang. Ayat-ayat tersebut ke semuanya ditujukan kepada mereka yang ingkar, di antara ayatnya adalah Surah al-An'am [6]: 37:

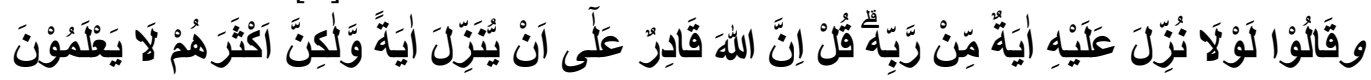
"Mereka orang-orang musyrik Mekkah berkata, mengapa tidak diturunkan kepadanya (Muhammad) suatu mukjizat (yang bersifat indrawi) dari Tuhannya? Katakanlah sesungguhnya Allah Kuasa (Qadir) menurunkan suatu mukjizat, tetapi kebanyakan mereka tidak mengetahui."

Jadi kata القدرة merupakan asal kedua kata berikut قدير - مقتدر merupakan suatu ungkapan tentang makna yang dengannya didapatkan sesuatu yang siap dengan ketetapan iradah dan ilmu yang terjadi atas kesesuaian dengan keduanya. Sedangkan, القدير ialah zat yang kalau Dia mau melakukan, dan kalau tidak mau Dia tidak lakukan dan bukan termasuk syaratnya untuk mesti menghendaki. Yang Kuasa secara mutlak itu ialah yang menciptakan segala sesuatu yang ada dengan penciptaan yang terdiri dan terlepas dari bantuan lainnya. Dia adalah Allah SWT (Shihab, 1999). Sedangkan hamba hanya memiliki kemampuan sebatas fitrahnya sebagai manusia. Oleh karena itu, ciptaan yang mampu dilakukan oleh manusia berupa kreativitas sesuai tabiat dasarnya sebagai hamba (Al-Qurthubi, n.d.: 465466).

Berakhlak dengan kedua isim ini mengharuskan seorang (pengawas) untuk tidak melalaikan sesuatu pun dari kehendak Allah sesuai dengan kemampuan pengawas pendidikan, dan mencurahkan segenap kemampuan dalam berbuat dan berbakti kepada-Nya guna mencari ridha-Nya.

Bila ditelusuri beberapa ayat yang berkaitan dengan isim (nama) ini, maka

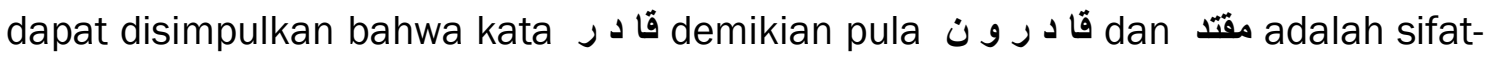
sifat Allah Yang Maha Kuasa itu. Tetapi, qudrah dan kekuasaan yang ditunjuk dari sifat tersebut lebih banyak ditujukan kepada para pembangkang dan yang tidak beriman sebagai ancaman atau siksa bagi mereka. Dapat pula dipahami sebagai penghalang niat buruk dan penindasan terhadap orang lemah, sejalan dengan sifat القوى (Shihab, 1999).

Memahami dan mempraktikkan sifat-sifat Allah sebagaimana dijelaskan di atas berimplikasi pada pembentukan karakter yang pengawas qur'ani. Pengawas 
yang mempraktikkan tiga sifat dasar yang harus dimiliki oleh setiap pengawas, yaitu: pencipta pertama (al-badi'), menyifati sifat Allah dan menjadikan karakter diri seorang pengawas akan melahirkan sosok pengawas yang inovatif, selalu memiliki ide-ide yang memajukan lembaga pendidikan di bawa pengawasannya. Selalu terdepan dalam inovasi peningkatan mutu pendidikan sehingga memaksimalkan potensi lembaga pendidikan mencapai tujuan pendidikan yang telah dicanangkan. Sifat selanjutnya adalah pertama (al-awwal) dan akhir (al-akhir), pengawas pendidikan yang mampu menyifati kedua sifat ini senantiasa menjadi pelopor dan pengawal ide-ide inovatifnya. Pengawas yang demikian inilah yang senantiasa dirindukan di lembaga pendidikan dan menjadi teladan dalam sikap dan perilakunya. Dirindukan karena ide-idenya yang inovatif dan selalu memberi solusi bagi tercapainya tujuan pendidikan. Diteladani karena ia selalu melakukan apa yang dicanangkan dan selalu mengawal ide-ide tersebut sampai terealisasi di lembaga pendidikan.

\section{PENUTUP/SIMPULAN}

Kegagalan pengawas pendidikan tidak hanya disebabkan karena profesionalisme yang kurang. Tetapi kegagalan utama pengawas pendidikan disebabkan faktor karakter yang belum mencerminkan karakter yang diajarkan dalam Islam. Kinerja buruk pengawas disebabkan karena anggapan bahwa profesi pengawas adalah posisi transisi ke masa pensiun atau bahkan profesi buangan, sehingga tidak tertanam dalam dirinya apalagi mempraktikkan sifat Allah inovatif (alBari') terdepan (al-awwal) dan mengawal kebijakan atau ide-ide inovatifnya (al-akhir). Pengawas yang menyifati ketiga sifat Allah tersebut dijamin akan melihat bahwa profesi pengawas adalah profesi mulia dan tugas dan fungsinya sejalan dengan tujuan Islam, menjadi penerang bagi seluruh manusia, terutama orang-orang yang berada di bawa pengawasannya.

Tulisan ini berkontribusi bagi pengembangan karakter pengawas dengan memperlihatkan bahwa dalam Al-Qur'an, sumber utama Islam, terdapat konsep karakter pengawas yang dapat diterapkan oleh negara di bawa kementerian agama di dalam membentuk karakter pengawas yang bertanggung jawab dan mampu menjadi teladan bagi orang-orang yang diawasinya dan bagi masyarakat di sekitarnya. Lebih lanjut bahwa Al-Qur'an memiliki solusi bagi menciptakan pengawas pendidikan yang profesional yang dibutuhkan lembaga pendidikan untuk mengawal dan memandu mereka mencapai tujuan pendidikan. Keterbatasan tulisan ini adalah masih merupakan konsep yang butuh penerapan di wilayah empiris, lembaga pengawas pendidikan. Keterbatasan lain bahwa proses pembentukan karakter tentu membutuhkan waktu dan tenaga untuk mencapainya. Selanjutnya bahwa konsep yang ditawarkan adalah konsep yang tidak umum dibicarakan di kalangan lembaga pendidikan, mengingat bahwa kajian ini masih membutuhkan pembuktian di lembaga pengawas dan belum diterima secara terbuka di kalangan kaum terdidik. 
Maka dibutuhkan kajian lebih lanjut dan memformulasikan konsep-konsep tersebut ke arah yang lebih empiris, misalnya kajian multidisipliner antara ahli agama, psikologi dan pendidikan.

\section{DAFTAR PUSTAKA}

Aedi, N. (2014). Pengawasan Pendidikan: Tinjauan Teori dan Praktik. Jakarta: PT. RajaGrafindo Persada.

Aguslani, A. (2019). Analisis Enam Kompetensi Pengawas Madrasah. Jurnal Balai Diklat Keagamaan Bandung, XIII(2), 220-229.

Al-Jily, A. S. A. K. bin I. (1975). Al-Insan Al-Kamil Fi Ma'rifatil Awakhir wal-Awail, Juz II. Beirut: Darul Fiqri.

Al-Jily, A. S. A. K. bin I. (2014). Insan Kamil: Ikhtiar Memahami Kesejatian Manusia dengan Sang Khaliq hingga Akhir Zaman. Surabaya: Pustaka Hikmah Perdana.

Al-Bagdad, A.-A. A. F. S. A.-S. M. al-A. (n.d.). Ruhul Maany: Fitafsiril Qur'anil Azhim wasSab'ul Matsany, Juz 27. Kairo: Dar al-Hadith.

Al-Qurthubi, A.-I. A. A. M. bin A. A. B. A.-A. (n.d.). Al-Jaamiul Li Ahkamil Qur'an, Juz I. Kairo: Dar Kutub.

Beddu, M., \& Fatnah, F. (2018). Pengaruh Supervisi Kepala Sekolah terhadap Disiplin Kerja Pegawai di SMP Negeri 1 Amali Kecamatan Amali Kabupaten Bone. $\begin{array}{lll}\text { Jurnal Idaarah, 37-49. } & \text { 2(1), }\end{array}$ https://doi.org/https://doi.org/10.24252/idaarah.v2i1.5148

Chairunnisa, C. (2016). Manajemen Pendidikan dalam Multi Perspektif. Jakarta: RajaGrafindo Persada.

Direktorat Pembinaan Pendidikan Agama Islam pada Sekolah Umum. (2000). Profesionalisme Pengawas Pendais (Irsal, A. K. Djaelani, \& Nursalim (Eds.)). Jakarta: Departemen Agama RI.

Erwin, E., Usman, S., \& Ibrahim, M. M. (2020). Implementasi Tugas dan Fungsi Pengawas Madrasah dalamPeningkatan Mutu Madrasah Aliyah seKecamatan Tanete Riattang kabupaten Bone. Jurnal Idaarah, 4(2), 256-266.

Krippendoff, K. (1993). Analisis Isi: Pengantar Teori dan Metodologi. Jakarta: Citra Niaga Rajawali Press.

Kurniati, K. (2020). Pendekatan Supervisi Pendidikan. Jurnal Idaarah: Manajemen Pendidikan,

52-59. https://doi.org/https://doi.org/10.24252/idaarah.v4i1.7894

Musdalifah, M. (2020). Supervisi Manajerial Profesi Guru dalam Jabatan. Jurnal Idaarah: Manajemen Pendidikan, 4(1), 119-128. https://doi.org/https://doi.org/10.24252/idaarah.v4i1.14062 
KONSEP PENGAWAS DALAM PERSPEKTIF AL-QUR'AN: UPAYA ...

Naisaburi, A. H. M. bin al-H. (n.d.). Shahih Muslim (J. 1 (Ed.)). Beirut: Daar Ihyaa alTuraats al-'Arabi.

Pagga, P., Getteng, A. R., Mustami, K., \& Syamsudhuda, S. (2020). Kinerja Supervisor dan Kreativitas Guru PAI. Jurnal Idaarah: Manajemen Pendidikan, 4(2), 129142. https://doi.org/https://doi.org/10.24252/idaarah.v4i2.15936

Pandong, A. (2003). Jabatan Fungsional Pengawas. Jakarta: Badan Diklat Depdagri dan Diklat Depdiknas.

RI, D. A. (2005). Kepengawasan Pendidikan. Jakarta: Departemen Agama RI.

Samsirin. (2015). Konsep Manajemen Pengawasan dalam Pendidikan Islam. AtTa'dib, 10(2), 341-360. https://doi.org/http://dx.doi.org/10.21111/attadib.v10i2.461

Shamad, Abdullah bin Abdurrahman bin al Fadhl bin Bahram bin Abdush. (n.d.). Sunan Ad-Daarimii. Saudi Arabia: Daar al-Mughnii.

Shihab, M. Q. (1999). Mengungkap Tabir Ilahi: Asma al-Husna dalam Perspektif AlQur'an. Jakarta: Lentera Hati.

Shihab, M. Q. (2010). Membumikan Nilai-Nilai Qur'ani. In H. M. Noer (Ed.), Masyarakat Qur'ani: Noktah Putih Kehidupan (pp. 71-86). Jakarta: Penamadina.

Syukur, A. (2015). Mengenal Corak Tafsir Al-Qur'an. El-Furqonia, 1(1).

Thaib, M. A., Siregar, S. S., \& Noer, H. M. (2005). Standar Supervisi dan Evaluasi Pendidikan pada Madrasah Aliyah. Jakarta: DITMAPENDA.

Undang-Undang Pendidikan Nasional. (2011). Pustaka Pelajar.

Wibowo, A. M., \& Muawanah, S. (2019). Pengawas dan Peningkatan Kualitas Pendidikan Madrasah Aliyah. Semarang: Balai Penelitian dan Pengembangan Agama Semarang.

Yunus, Y. (1989). Menjaga Nama Islam. Bandung: Penerbit Pustaka. 